\title{
Groundwater flow dynamic investigation without drilling boreholes
}

\author{
Mahmoud Moustafa
}

Received: 16 March 2014/Accepted: 5 February 2015/Published online: 20 February 2015

(C) The Author(s) 2015. This article is published with open access at Springerlink.com

\begin{abstract}
The flow net map is a basic tool for groundwater flow dynamics investigation. In areas where there are no boreholes or piezometers are not available, constructing flow net map may be difficult. This work proposes a simple methodology to construct flow net map without drilling boreholes. The flow net map constructed using the proposed approach represents an expected flow net map, which can draw conceptual flow model of the site. The major benefit from constructing the expected flow net map is it gives guidance for locating new boreholes for site investigation, carrying out investigation of the groundwater flow directions and estimating recharge/discharge from the site boundary. An illustrative example for the proposed approach was presented to show how the data required to construct the expected flow net map can be collected. The constructed, expected flow net map using the proposed methodology was compared with actual flow net map constructed from measured water levels. Both maps give consistent hydrological information about the site. The suggested approach represents a simple and cheap way to carry out investigation of groundwater flow dynamics in areas where there are no boreholes are available.
\end{abstract}

Keywords Groundwater - Flow direction - Flow net construction $\cdot$ No boreholes

\section{Introduction}

Constructing flow net map is a well-accepted practice in investigation of groundwater flow directions. A flow net is a $2 \mathrm{D}$

M. Moustafa $(\bowtie)$

Faculty of Petroleum and Mining Engineering, Suez University, Suez, Egypt

e-mail: m.h.moustafa@gmail.com diagram of equipotential and flow lines (Braja 2013; Casagrande 1940; Driscoll 1986; Freeze and Witherspoon 1967). The flow net map can be used to estimate the quantity of recharge across site feeding front boundary, and contaminant load can be estimated from flow net map (Harr 1962; Domenico and Schwartz 1990). Flow net can show the topographic control of groundwater flow (Fetter 1988). To construct a flow net map, water levels are measured in a network of boreholes and their surfaces are interpolated between measuring points (Fels and Matson 1996). Water table surface is a representation of the surface of saturated zone, below which all the geological formation voids are fully filled with water (Heath 1988). Position of the water table is a result of natural processes controlling the rate at which water enters and leaves the saturated zone. If the rate of water enters the saturated zone (recharge) exceeds the rate of water leaving (discharge) the aquifer, the water table rises and vice versa. The water table surface is not static, nor flat, but reflects the climatic, vegetative and geomorphic conditions. The groundwater water table could be subdued replica of the land surface (King 1899; Domenico and Schwartz, 1990).

Groundwater aquifer investigation in an area requires drilling boreholes to know the water depth to determine water level and construct flow net map. Having constructed a flow net map, groundwater flow dynamics such as pressure head distribution throughout the aquifer, flow direction, hydraulic gradient and definition of discharge/recharge areas can be studied (Freeze and Cherry 1979; Fitts 2012). All above benefits from flow net map cannot be obtained if there are no boreholes at the study site. Resistivity measurements with Schlumberger array configurations (Zohdy et al. 1974) are considered one of the best configurations for water depth sounding to explore the groundwater aquifer occurrences. In this configuration, the center point of the electrode array remains fixed; however, the spacing between the electrodes 
Fig. 1 Study site location at Naama Bay, Egypt

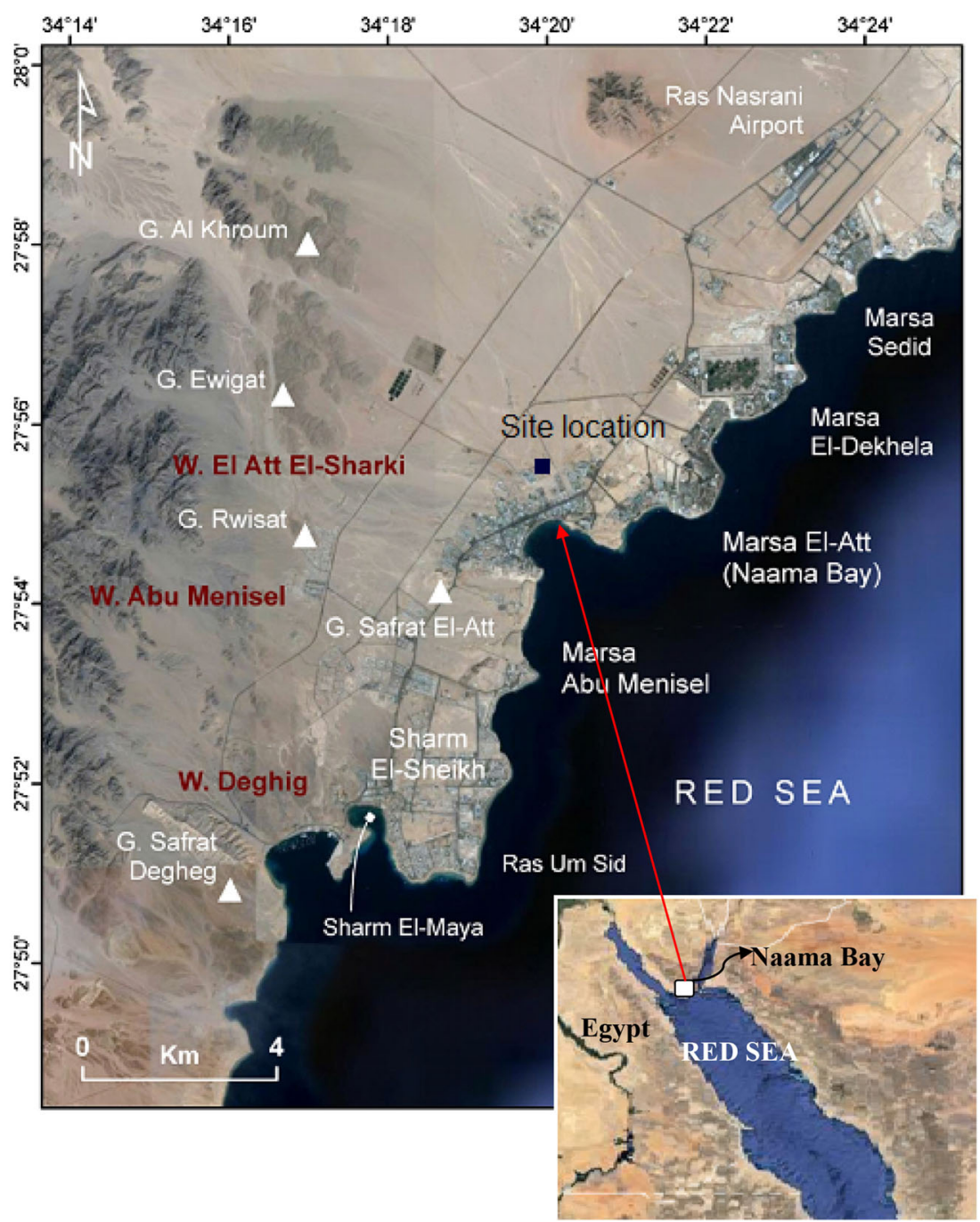

Table 1 Estimated water depth from geo-electric survey and calculated water level

\begin{tabular}{llllll}
\hline Point & $\begin{array}{l}\text { Longitude } \\
(\text { decimal }) \text { from }_{\text {GPS }^{\mathrm{a}}}\end{array}$ & $\begin{array}{l}\text { Latitude (decimal) } \\
\text { from GPS }^{\mathrm{a}}\end{array}$ & $\begin{array}{l}\text { Height above sea level } \\
(\mathrm{m}) \text { from Google Earth }\end{array}$
\end{tabular}

${ }^{a}$ Coordinates obtained from GPS

${ }^{\mathrm{b}}$ Height of points estimated from Google Earth

${ }^{c}$ Calculated water level using water depth from geo-electric survey and Eq. (1)

is increased in a progressive way to obtain more information about the subsurface layers.

This work proposes a simple nondestructive methodology to construct water level and flow net maps in regions where there are no boreholes. The methodology was applied to a site to show how the required data for the methodology can be collected.

\section{Study site}

The study site is located in Naama Bay, Egypt (Fig. 1). Naama Bay lies in the region which extends from Ras Mohamed in the south and Taba in the north. South Sinai has many watercourses (wadies) some of which run in the north-south direction and extend to Suez Gulf and Naama 


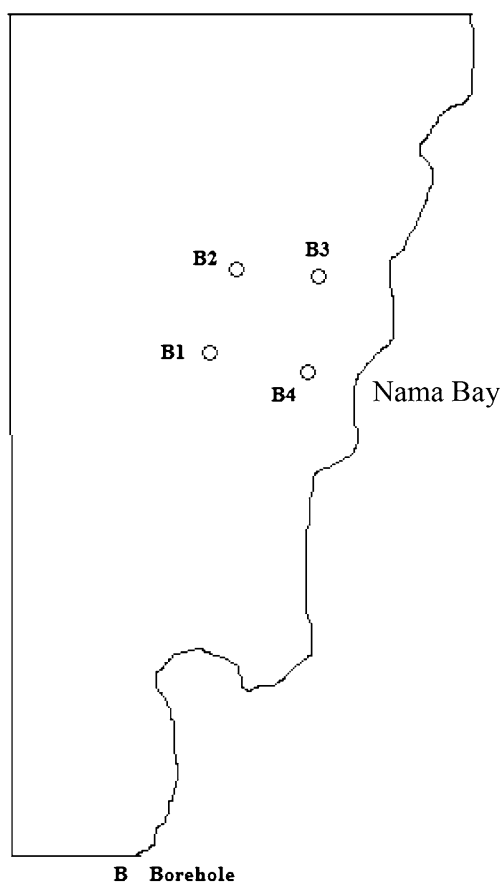

Fig. 2 Sketch of site location with borehole location



Fig. 3 Schlumberger array used to detect water depth at each of the selected points where $A$ and $B$ are electrical current polars, $M$ and $N$ are electrical potential polars

Bay. Sinai consists of three main sections. Northern section consists of sandstone, middle one consists of limestone, and the southern section where study site located consists of granitic rocks coved in some parts with limestone, sandstone and quaternary deposits (Hume 1906).

\section{Materials and methods}

To construct a flow net map without drilling boreholes, three approaches were applied.

1. GPS (Global Positioning System) (NUS, 1995): GPS was used to define the coordinates of four points selected in the site (Table 1; Fig. 2).

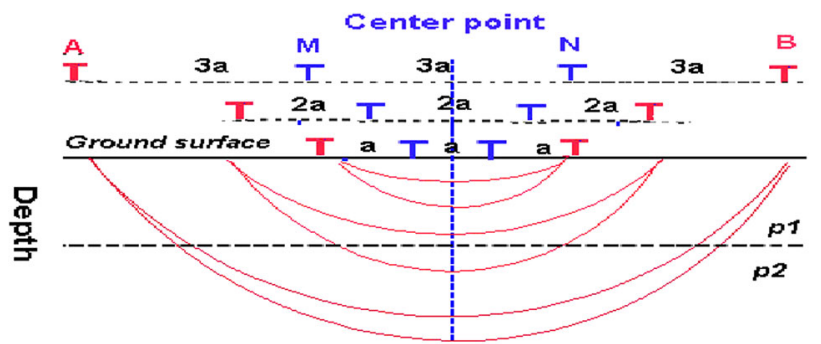

(b) Resistivity Sounding

Fig. 4 Positions of electrical polars during investigation

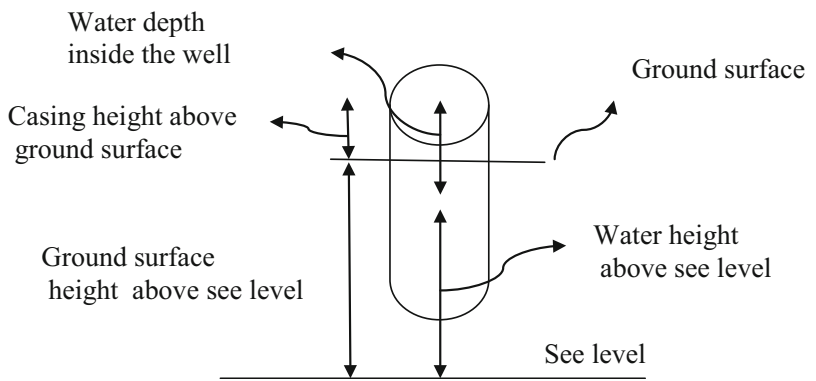

Fig. 5 Layout to estimate water level above sea level from measured depth to water in four boreholes

2. Google Earth: Using the coordinates of the four points and Google Earth, the height of the selected points above sea level was measured (Table 1).

3. Geo-electric survey was applied to estimate water depth at the four selected points. Geo-electric technique with Schlumberger layout (Fig. 3) was applied. The method is based on the estimation of resistivity of the medium. An apparent resistivity is calculated from a resistance value and geometric factors that account for the electrode spacing configuration. Estimation is performed based on the measurement of voltage of electrical field induced by the distant grounded electrodes (current electrodes). The interpretation of the measurements can be performed based on the apparent resistivity values. The depth of investigation depends on the distance between the current electrodes. In order to obtain the apparent resistivity as the function of depth, the measurements for each position are performed with several different distances between current electrodes. The measurements were taken using $200 \mathrm{~m}$ distance between polars A and B to know the subsurface layers till $70 \mathrm{~m}$ depth (Fig. 4). Resistivity curves were plotted on logarithmic scale between resistivity value and distance $A B / 2$. RESIST software was used to analyze the data. Estimated water depth values are indicated in Table 1.

4. Geo-electric cross section for the site in the west-east direction. 
Table 2 Data used in constructing actual flow net map using measured water depth values

\begin{tabular}{llllll}
\hline $\begin{array}{l}\text { Point } \\
\text { (decimal) from }\end{array}$ & $\begin{array}{l}\text { Longitude } \\
\text { GPS }\end{array}$ & $\begin{array}{l}\text { Latitude } \\
\text { GPS }\end{array}$ & $\begin{array}{l}\text { Height above sea level } \\
(\mathrm{m}) \text { from Google Earth }\end{array}$ & $\begin{array}{l}\text { Measured water depth } \\
(\mathrm{m}) \text { in drilled boreholes }\end{array}$ & $\begin{array}{l}\text { Water levels above sea level (m) in drilled } \\
\text { boreholes above sea level (m) }\end{array}$ \\
\hline 1 & 34.33156729 & 27.925 & 28.485 & 19.8 & 8.685 \\
2 & 34.33098793 & 27.9248 & 28.864 & 19.95 & 7.964 \\
3 & 34.3322432 & 27.9244 & 25.804 & 22.6 & 2.704 \\
4 & 34.33167458 & 27.9243 & 24.756 & 21.89 & 2.756 \\
\hline
\end{tabular}

${ }^{a}$ Water level calculated using Eq. (1) and water depth measured in drilled wells

Fig. 6 Vertical apparent resistivity curve

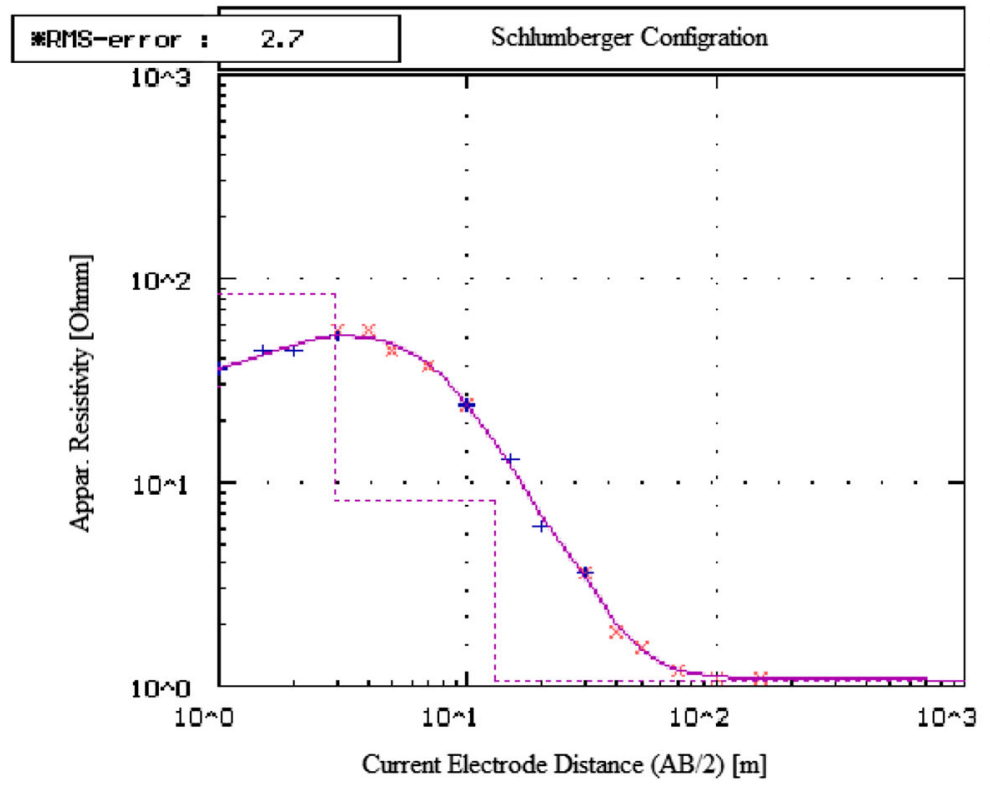

No Res Thick Depth

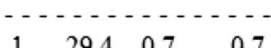
$\begin{array}{llll}2 & 83.6 & 2.3 & 2.9\end{array}$ $\begin{array}{llll}3 & 8.2 & 10.0 & 12.9\end{array}$ $4 \quad 1.1 \quad-\quad-$

* RMS on smoothed data
Fig. 7 Interpretative geological cross section through the study site (personal communication)

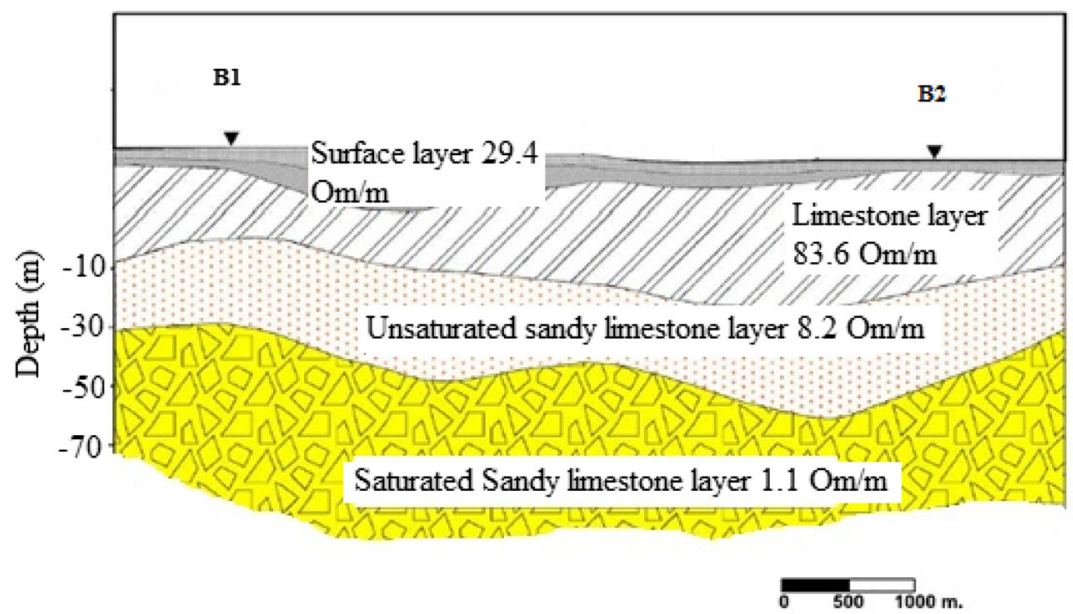

5. The water level above sea level at the four selected points was calculated based on Eq. (1) (Table 1).

Water level above sea level

$=$ Height of point above sea level

- Water depth at same point
- Four boreholes were drilled at same locations of the four points, the water depth was measured, and the water level was calculated according to Eq. (1) and Fig. 5. The measured water depth and calculated water levels are indicated in Table 2.

- Measured water depth values (Table 2) at the selected points were collected from the boreholes drilled at same 


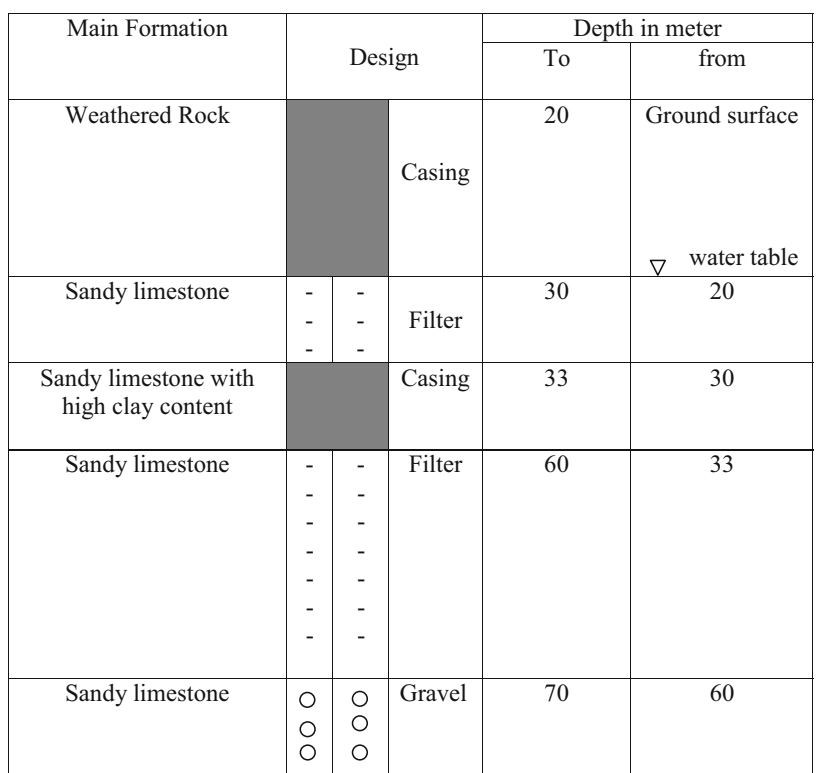

Fig. 8 Lithology of borehole drilled in the site

points by private sector. The water levels at drilled boreholes above sea level (Fig. 4) were calculated from Eq. (2).

Water level inside borehole above sea level

$=($ ground surface level + casing height $)$

- Depth to water inside the borehole
Where casing height above ground surface $=10 \mathrm{~cm}$

\section{Results and discussion}

Water depth estimation and subsurface characterization

From geo-electric survey, Figs. 6 and 7 revealed that there are four layers. Top surface layers have $0.7 \mathrm{~m}$ thickness with resistivity $29.4 \mathrm{Ohm} / \mathrm{m}$ followed by unsaturated layer from limestone with resistivity 83.6 $\mathrm{Ohm} / \mathrm{m}$, with thickness $2.3 \mathrm{~m}$. This layer, underlined by unsaturated sandy limestone intercalated with clay, has $8.2 \mathrm{Ohm} / \mathrm{m}$ resistivity and $10 \mathrm{~m}$ thickness. Finally, a saturated sandy limestone layer extends to $40 \mathrm{~m}$ with low resistivity $(1.1 \mathrm{Ohm} / \mathrm{m})$ maybe due to saline water. The transition of resistivity values from $83.6 \mathrm{Ohm} / \mathrm{m}$ at $3.3 \mathrm{~m}$ depth from ground surface to resistivity of $8.2 \mathrm{Ohm} / \mathrm{m}$ in the unsaturated layer at $20 \mathrm{~m}$ depth is interpreted to represent the water depth ranges from 18 to $20 \mathrm{~m}$ below ground surface. This may be consistent with depth to water measured in boreholes drilled at the site (Table 2). The lithology of the drilled borehole is indicated in Fig. 8.

Site topography characterization

From four selected points, coordinates obtained from GPS technique topography map was constructed. It indicates
Fig. 9 Topographic map of the site based on data columns 2,3 and 4 in table (1)

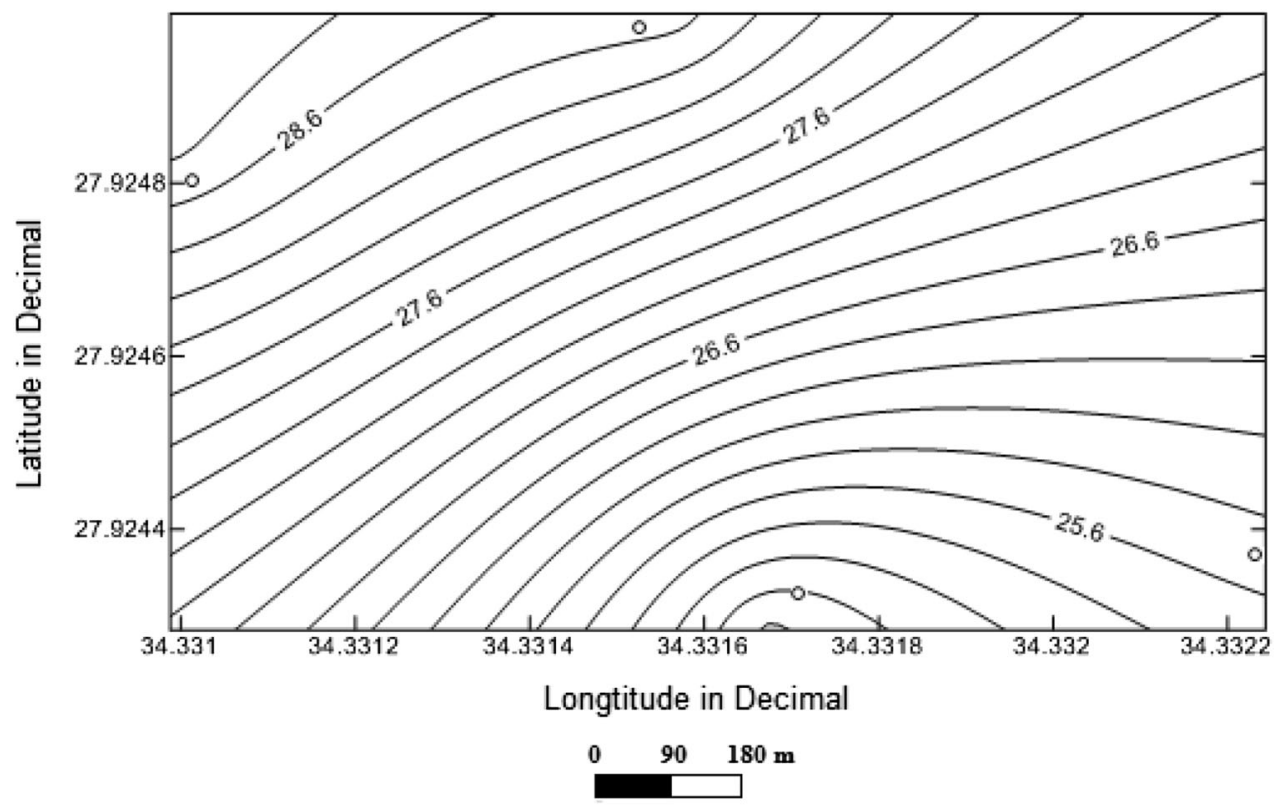

○ The four selected point locations 
Fig. 10 Expected distribution map for water depth in the site using depth to water inferred from geo-electrical survey data from Table 1

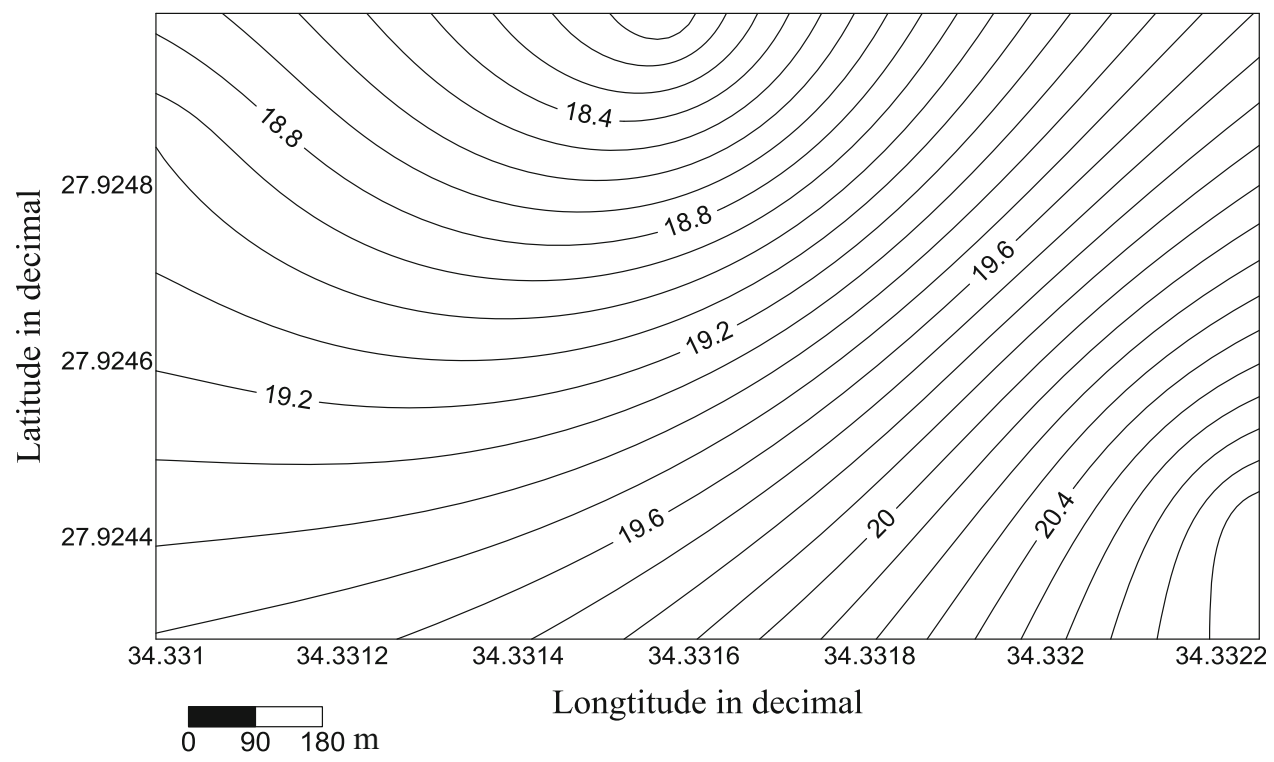

o Borehole location

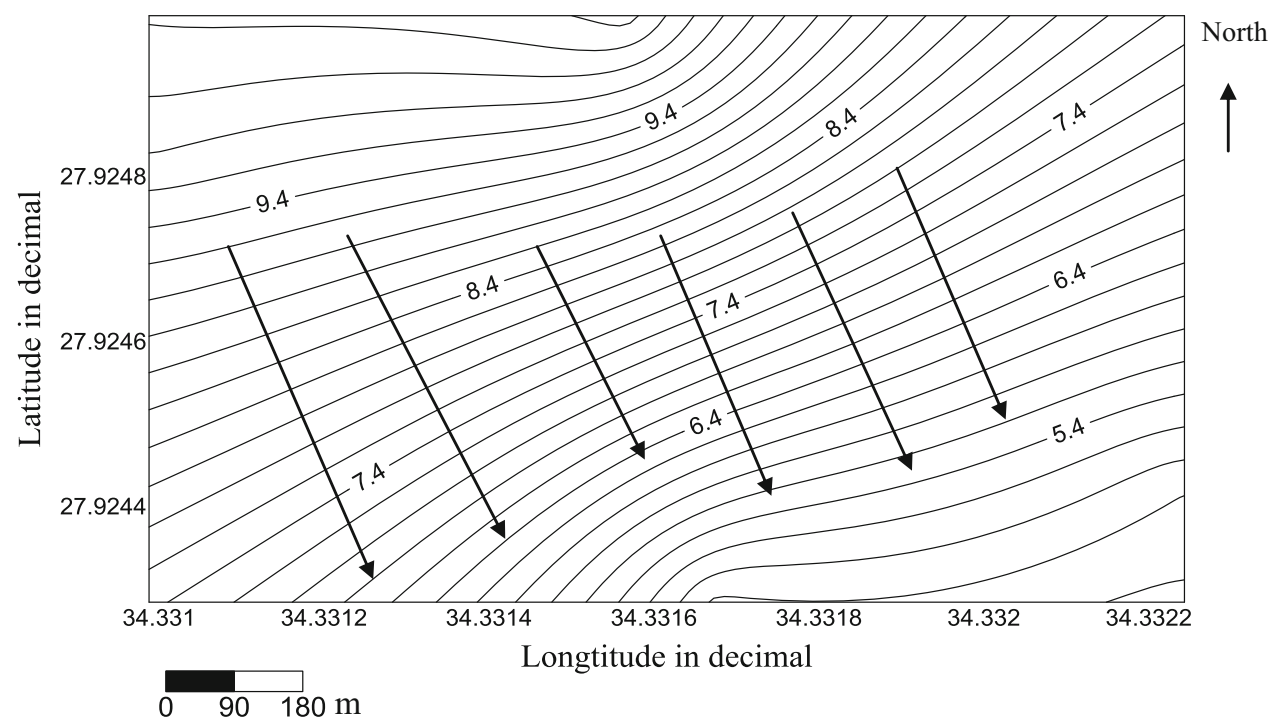

o Boreholes locations
Fig. 11 Expected flow net map constructed using estimated water depth from geo-electric survey data from Table 1 that the site has gentle slope from all sides running toward Naama Bay shoreline (Fig. 9).

Groundwater dynamics investigation

\section{Construction of depth to water map}

Water depth information is important in locating and designing water wells. Water depth distribution map in the study site was constructed using water depth collected from geo-electric survey (Table 1). water depth in the site (Fig. 10) is deep by (18 m) in high topographic areas on the left side of the area and deep by $(20 \mathrm{~m})$ in low topographic land in the south and southeast of the site. water depth lines in the area suggest subdued replica of ground surface topography (King 1899; Daniel 1989). Although Todd (2005) suggested that surface geo-electric survey could not give an accurate water surface, many authors such as Nigm (2013), Sabet (1975) and Douglas (2013) indicated that inferred depth of water from resistivity survey could be consistent with the values measured in boreholes. The measured values of water depth in four boreholes (Table 2) could be consistent with that estimated from geo-electric surface taking into account borehole diameter may have an effect on the final position of water surface inside the well (Lohman 1972). Water depth map 
Fig. 12 Actual flow net map from measured water depth in four boreholes

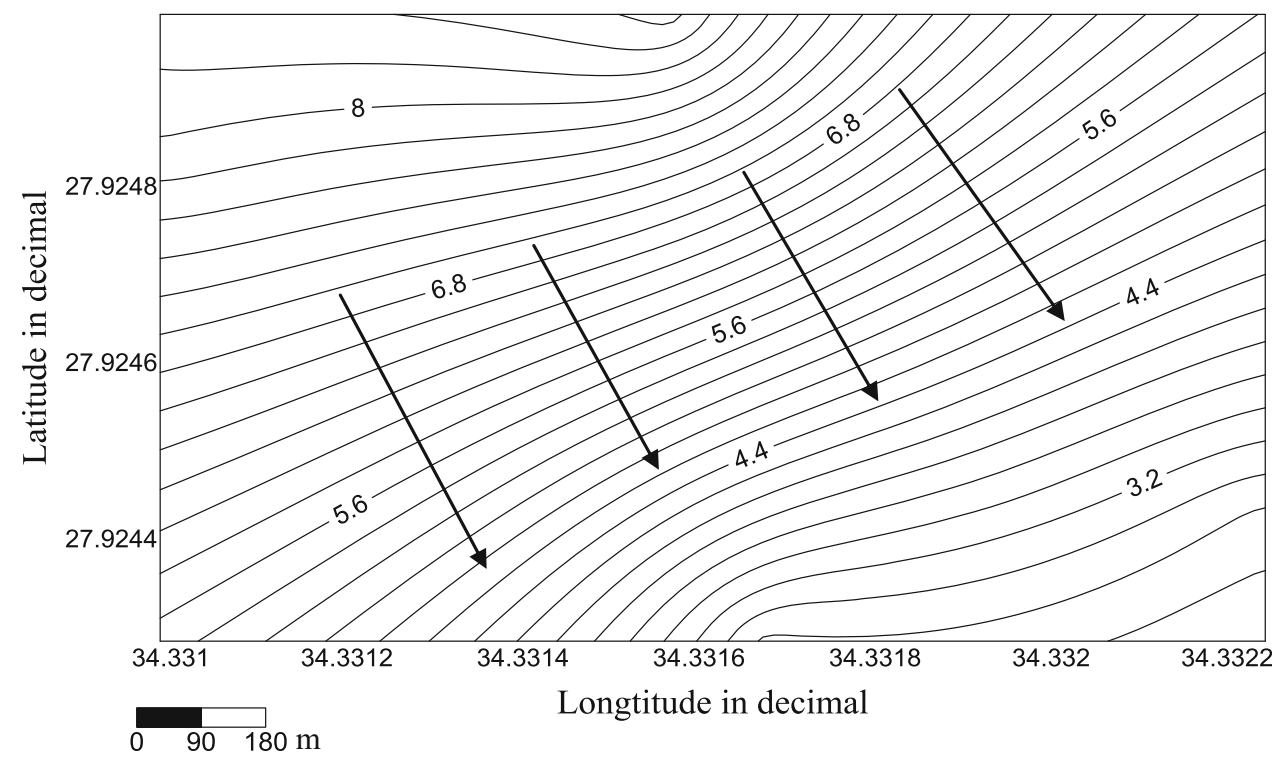

from measured values is consistent with water depth distribution map with that obtained from estimated water depth as shown in Fig. 10.

\section{Expected and actual flow net map}

The expected flow net map (Figs. 11, 12) was constructed based on data collected from the suggested methodology (Table 1), where the water level was calculated from depth to water estimated from geo-electric survey and elevations of points above sea level obtained from digital elevations from Google Earth with GPS (longitude, latitude) coordinates. This map indicates that the groundwater moves from north to south and southeast of the site toward Naama Bay shoreline. Groundwater in the area discharges into the south end of the site (shoreline of Naama Bay). Recharge to the site comes from the around highlands, from the north, northeast and northwest side. This may be consistent with watercourses (wadies with alluvial deposits) which are running in north-south direction. The inflow or outflow quantities can be estimated by applying the Darcy law (Braja 2013). The expected flow net map was compared with actual flow net map constructed using measured depth to water values in four boreholes drilled by private sector (Table 2). Although the measured depth to water is slightly different from that estimated from geo-electric survey, the expected flow net map gives consistent hydrological information about groundwater flow direction in the site. The general groundwater flow direction was nearly the same at both flow net maps (expected and actual map). A sensitivity analysis for the accuracy of the expected flow net map was carried out, where the measured water depth values were changed by varying percentages from the estimated values. It was found that if the error percentage between the estimated and measured water depth is constant at all measuring points (wells), both the expected and actual flow net maps are giving same hydrological information about groundwater flow direction regardless of the error value.

\section{Conclusion}

In areas where there are no boreholes or information about groundwater level and direction, expected flow net map of the site can be constructed without drilling boreholes, using the suggested simple nondestructive methodology to study groundwater flow dynamics and contaminate migration. Comparing the flow net map using water levels estimated from the suggested approach to that constructed from measured water depth values gives same hydrological groundwater flow information concerning flow direction and recharge/discharge areas. If the errors between estimated water depth from resistivity survey and that measured in boreholes were constant at all measuring points, both actual and expected flow net map have the same hydrological conclusion.

Open Access This article is distributed under the terms of the Creative Commons Attribution License which permits any use, distribution, and reproduction in any medium, provided the original author(s) and the source are credited.

\section{References}

Braja M (2013) Principles of geotechnical engineering, 7th edn

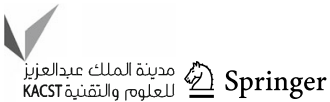


Casagrande A (1940) Seepage through dams in contributions to soil mechanics: 1925-1940, Boston Soc. Civil Engineers

Daniel CC (1989) Statistical Analysis Relating Well Yield to Construction Practices and Siting of Wells in the Piedmont and Blue Ridge Provinces of North Carolina (US Geological Survey water-supply paper 2341-A). US Government Printing Office, Washington, DC

Domenico PA, Schwartz FW (1990) Physical and Chemical Hydrogeology. Wiley, New York

Douglas HA (2013) Geoelectrical detection of water table depth at two locations in the Los Osos groundwater basin. A Senior Project, Faculty of the Natural Resource Management and Environmental Science Department. California Polytechnic State University, San Luis Obispo

Driscoll FD (ed) (1986) Groundwater and wells. Johnson Screens, St Paul

Fels JE, Matson KC (1996) A cognitively-based approach for hydrogeomorphic land classification using digital terrain models. In: Proceedings, Third International Conference on Integrating GIS and Environmental Modeling, National Center for Geographic Information and Analysis, Santa Barbara (WWW, CD)

Fetter CW (1988) Applied hydrogeology. Nerrill Pub Co., A well and Howell information Co., Columbia, p 529

Fitts C (2012) Groundwater science. 2nd edn, Hardbound

Freeze RA, Cherry JA (1979) Groundwater: Prentice-Hall. Englewood Cliffs, NJ, pp 174-178

Freeze RA, Witherspoon PA (1967) Theoretical analysis of regional groundwater flow, 2. Effect of water-table configuration and subsurface permeability variation: Water Resour Res 3:623-634

Harr ME (1962) Groundwater and seepage, McGraw-Hill, New York, p 315
Heath RC (1988) Hydrogeologic Settings of Regions. In: Back W, Rosenshein JS, Seaber PR (eds) Hydrogeology. Geological Society of America, Boulder

Hume WF (1906) The topography and geology of Peninsula of Sinai. South-eastern portion, Cairo

King FH (1899) Principles and conditions of the movements of groundwater. US Geological Survey 19th Annual Report, Part 2, pp 59-294

Lohman SW (1972) Groundwater hydraulics. Geological Survey Professional (708)

National Research Council (N.U.S.) (1995) Committee on the Future of the Global Positioning System; National Academy of Public Administration. The global positioning system: a shared national asset: recommendations for technical improvements and enhancements. National Academies Press, Chapter 1, p 16 (ISBN 0-309-05283-1. Retrieved 2013-08-16)

Nigm A (2013) Geoelectric study for water well location in the campus of Taif University, Taif, Saudi Arabia. Int J Water Resour Arid Environ. 2(4):195-204 (ISSN 2079-7079)

Sabet MA (1975) Vertical electrical resistivity soundings to locate ground water resources: a feasibility study. Department of Geophysical Sciences, Old Dominion University, Norfolk, pp 329-346

Todd DK, Mays LW (2005) Ground-water hydrology, 3rd edn. Wiley, NewYork, p 636

Zohdy A, Eaton GP, Mabey DR (1974) Application of surface geophysics to ground-water a correlation between the different models of investigations: U.S. Geological Survey Waterresistivity sounding data to discover new fresh resources Investigations, Book 2, Chapter D1, p 86 